\title{
The Sustainable Marketing Mix of Tourism and Visitors Fulfilment: An Empirical Evidence From Cultural Tourists To Pakistan
}

\author{
Asia Umar Khan \\ Ph.D. Scholar, Department of Management Sciences \\ Islamia College Peshawar. Pakistan \\ asia-umar@icp.edu.pk \\ Dr. Qadar Bakhsh Baloch \\ Professor, Institute of Business Studies and Leadership \\ Abdul Wali Khan University, Mardan \\ qbbaloch@awkum.edu.pk \\ Rabia Naseer \\ Lecturer, Department of Management Sciences \\ Islamia College Peshawar, Pakistan \\ rabia.naseer@icp.edu.pk
}

\begin{abstract}
Sustainability is a basic requisite while promoting cultural tourism for a destination. UNEP and WTO have provided a full agenda for sustainable tourism that consists of twelve aims. One of those aims is visitor fulfillment that includes tourist satisfaction provided with safety and justice. After an extensive literature review the present study has listed down the success factors of tourism marketing and viewed through the lens of sustainability aims, has developed a conceptual framework consisting of the marketing mix dimensions of sustainable tourism and their effect on satisfaction of a sample (400) of foreign cultural tourists to Pakistan. After exploratory and confirmatory factor analysis, multiple regression analysis was conducted to test for the hypothesized effect of the seven independent variables i.e. Product Price, Placement, Promotion, People, Physical Evidence and Process on tourist satisfaction. It was found that Product, Price, People, Physical Evidence and Process have a significant positive whereas; Placement has aninsignificant negative and Promotion has a significant negative effect on tourist satisfaction.
\end{abstract}

Key Words: Sustainable Marketing Mix of Tourism, Visitor Fulfillment, Cultural Tourists, Pakistan

\subsection{Introduction}

Sustainability and sustainable development are nowadays hot topics of concern especially in developed countries of the world like North America; Europe and others. The World 
Summit on Social Development (2005) identified three principal areas that add to the philosophy and social science of sustainable development. i.e.i) Economic development; ii) Social development and iii) Environmental protection. It means that any activity would add to the sustainable development which is environment friendly and contributes to social and economic development of a country. As far as tourism is concerned, it can be viewed as one of the mostprofitable industriesthat generate capital investment and foreign exchange earnings. Tourism generates social as well as economic wellbeing which is evidenced by the income and remunerations that result from investments in this sector, and is especially important for developing countries (Megatef, 2015; UNEP \& WTO, 2005a).According to UNWTO (2014), tourism ensures not only income multiplier effect but also an employment multiplier effect on the economy. Unfortunately, in developing countries like Pakistan, UNEP (2005b) reported that entrepreneurs lack marketing skills and knowledge due to which they fail to position their product properly and face difficulties in market segmentation. Moreover, they fail to identify customer needs and associated perceived risks. Therefore, being a culturally rich country, there is an immense need to identify weaknesses in marketing of sustainable tourism of Pakistan so that proper marketing strategies could be sought to help policy makers and tourism industry in promoting a sustainable tourism in the country. Since various studies have been found that addressed the area of tourism marketing mix, since, scarcity was found in the area of sustainable cultural tourism marketing especially in a developing country like Pakistan.

\subsection{Research Questions}

RQ1: What are the underlying success factors and dimensions of marketing mix of sustainable cultural tourism?

RQ2: What is the effect of marketing mix dimensions of sustainable cultural tourism on satisfaction of tourists to cultural festivals, museums, and historical sites in Pakistan?

\subsection{Objectives of the study}

RO1a: To establish a relationship that explains the effect of marketing mix dimensions of sustainable cultural tourism on tourist satisfaction.

RO1b: To determine and explain the underlying factors from literature review that makeup each dimension of marketing mix of sustainable cultural tourism.

RO2a: To determine the effect of marketing mix dimensions of sustainable cultural tourism on satisfaction of tourists to cultural festivals, museums, and historical sites in Pakistan.

\subsection{Literature Review}

\subsubsection{Cultural Tourism}

The World Tourism Organization (1985), Tighe (1991), Boyd (2002) and Leslie \&Sigala (2005) define cultural tourism as type of persons' travel withintentions of exploring arts, cultural festivals, historical monuments, folklore and offering pilgrimages etc. Simply to say, cultural tourism is one in which the motivation of tourist is one or more of the 
cultural temptations of a site like museums, melodies, dramas, handiworks and religious events like pilgrimages etc.

This concept is presented in the following figure.2.1.

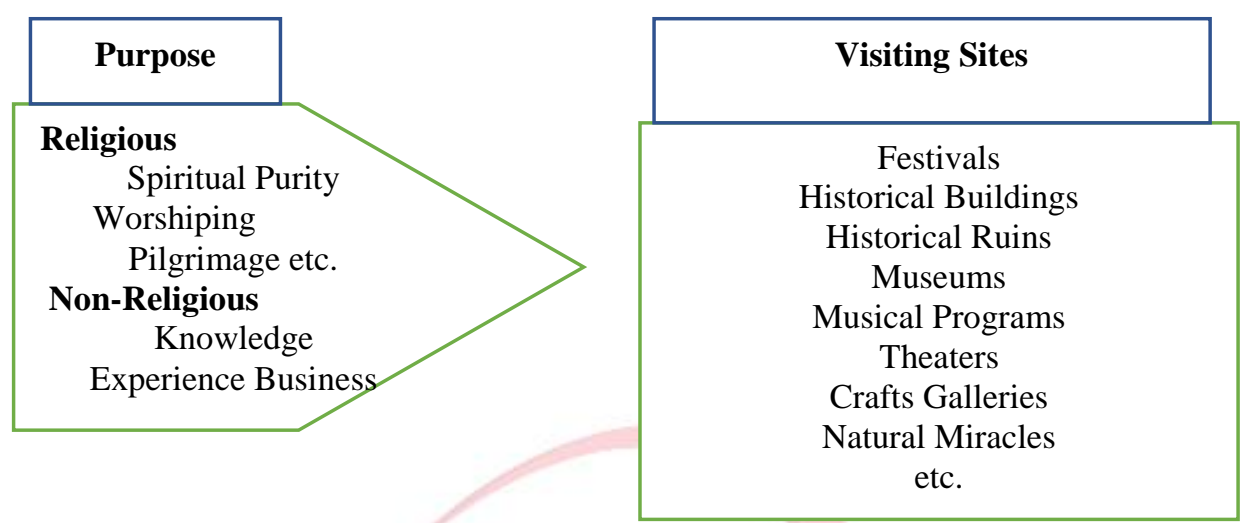

Source: World Tourism Organization (1985), Tighe (1991), Goodrich (1997), Boyd (2002),Shackley(2003), Leslie \&Sigala (2005), Raj \&Morpeth (2007) \&Petroman et.al. (2013).

\section{Figure.1. Purpose and Visiting sites of Cultural Tourists}

\subsubsection{Sustainable Cultural Tourism: A stakeholders Approach}

Cultural tourism plays akey role in sustaining and distinguishing the value of heritage. It is a key source for exchanging, stimulating and bringing variety in the culture however;while promoting cultural tourism for a destination, sustainability should be ensured (Hieu\&Rašovská, 2017). The tenets of sustainability signify the formation of appropriate balance between environmental, economic and socio-cultural aspects of tourism developmentThe UNEP and WTO (2005) has specified the complete definition of sustainable tourism highlighting the need to make all tourism sustainable. Articulated simply, sustainable tourism can be said to be:

"Tourism that takes full account of its current and future economic, social and environmental impacts, addressing the needs of visitors, the industry, the environment and host communities." (p.12)

One of the major aims of sustainable tourism is to maintain a top level of tourist satisfaction, thereby ensuring a fulfilling and meaningful experience to the tourist (UNWTO, 2012).For the attainment of these aims, UNEP and WTO (2005) has developed a 12 items agenda that may be used as a framework for developing policies for maximizing the positive and minimizing negative impacts of tourism promotion in order to achieve sustainability.

\subsubsection{Sustainable Tourism and Visitor Fulfilment}

As stated by UNEP and WTO (2005), visitor fulfilment is one of the basic aims of sustainable tourism. Explanation of visitor fulfilment from sustainable tourism reveals three dimensions of tourism service i.e.

- Safety of the tourists should be ensured; 
- The tourism service should be like that increases their delight and satisfaction; and

- Provision of tourism service must be without any discrimination of tourist.

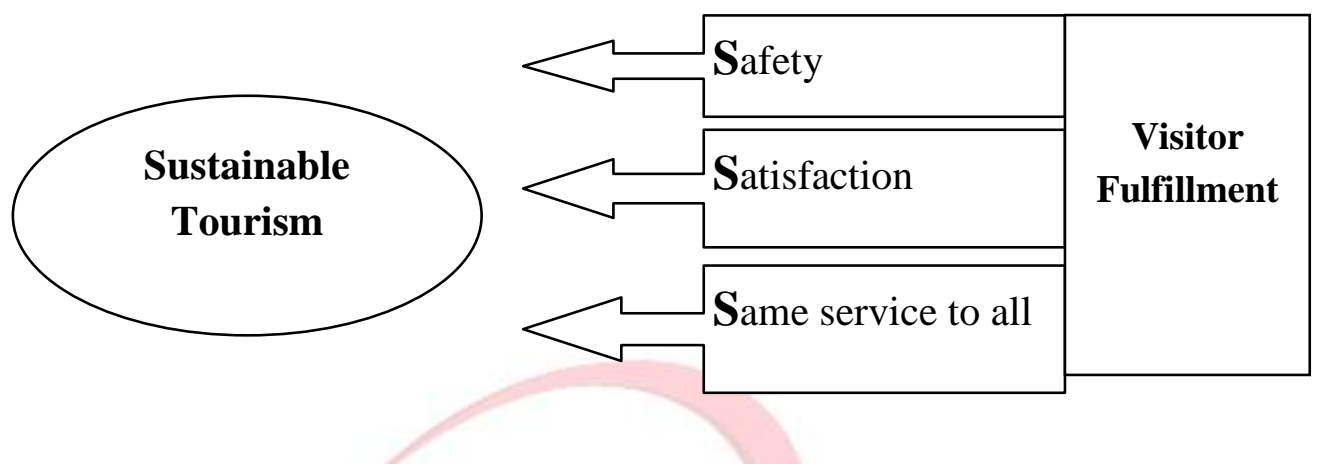

Source: Adapted from UNEP \& WTO (2005)

Figure: 2. The "Three S" Model of Visitor Fulfillment for Sustainable Tourism

These three dimensions are briefly discussed as following;

\subsubsection{Safety of Tourist}

One of the pre-requisite of sustainable tourism is the safety of tourists in the host country.According toAmir, Ismail and See (2015) provision of a safe and secure environment to visitors is the main determinant of success or failure of a tourism destination.It is stated by UNWTO (1996) as;

"Safety and security are vital to providing quality in tourism. More than any other economic activity, the success or failure of a tourism destination depends on being able to provide safe and secure environment for visitors"

Echtner and Ritchie (1991) also endorse the statement of UNWTO (1996) by arguing that creation and management of safe image of a destination is pre-requisite forits effective positioning and marketing strategy. Tourists being unfamiliar and temporary visitors to societies are unaware of the "safe" and "unsafe" regions or conducts. Tourists want a safe and secure destination to visit. According to Fuchs and Reichel (2006), when deciding upon a tourism product or service, the tourist might face different types of risks including physical harm due to any disease, misconduct or terror, regarded as non-monetary price by (Sran, 2014). However, if they have a perception of a destination as having risk or no safety, terrorism, misconduct of behavior and disease etc., but find the site safe and secured at their visit, might result in a higher level of satisfaction and delight (Oliver, 1980).

\subsubsection{Satisfaction of Tourist}

The importance of studying tourist satisfaction, a pre-requisite of sustainable tourism (UNEP \& WTO, 2005), lays in the fact that number of tourists that may repeat their visit to the same site, is surely determined by the level of their satisfaction from their first visit (Aziri\&Nedelea, 2013). Even if they are not interested in repeating their visit to the same 
site, still their satisfaction is important because their satisfaction may create a good word of mouth for those friends and family members who may like to visit the site in future (Lovelock, Patterson \& Walker, 2001; Marcussen, 2011). Also, the success of marketing strategies for all components of marketing mix for a destination relies on the satisfaction of tourist as it influences the selection of a destination and the duration of stay over there. (Yoon \&Uysal, 2005).

the "Expectation-Confirmation Theory" of Oliver (1980) which states that every consumer forms some expectations about the product before purchasing it. Then the level of satisfaction depends upon the extent to which the perception of a consumer matches with expectations about the product. If the perception equals or is greater than expectations, the consumer will be satisfied. This satisfaction level determines his/her loyalty and intentions to repurchase the product. It is showed in Fig.2.9.

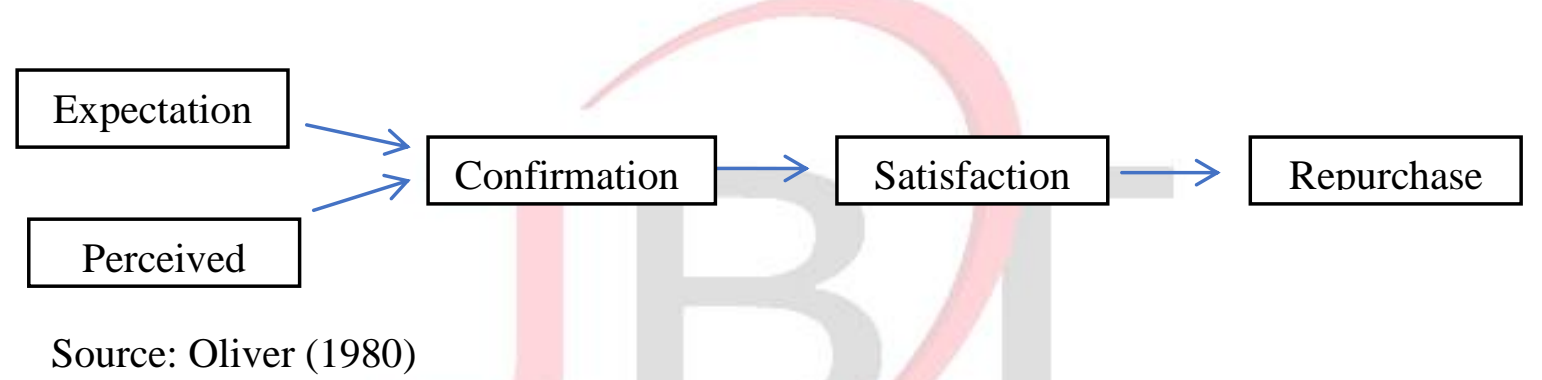

Figure.3. Expectation-Confirmation Theory

\subsubsection{Same Service to All Tourists}

Third requirement of visitor fulfillment for sustainability of tourism is to provide the same tourism service to all tourists without any discrimination on demographic basis (UNEP \& WTO, 2005). This is possible, especially in case of supporting product of cultural tourism where, same destination or historical site is visited by tourists but in case of supplementary component of tourism service, similarity of service to all tourists should be ensured. Besides this, for marketing and management of any kind of tourism the foremost and important task is to understand the characteristics of tourists that usually include socio-demographic characteristics and travel characteristics. It helps the tourism managers to design better marketing strategies, provide better services to tourists and hence increase their level of satisfaction (Gaffar, Wetprasit, H.P. \&Setiyorini, 2011;Phosikham, Vilayphone, Phimavong\&Wayakone, 2015).

\subsection{The Underpinning Theory of the Study: Marketing Mix by Booms and Bitner (1981)}

The concept of marketing mix for a service firm like tourism was first coined by Booms and Bitner (1981). They extended the concept of marketing mix of four Ps for a tangible product to a seven Ps model for a service firm. They suggested that for a service firm, modifications should be done not only to the traditional 4Ps butthree extra Ps also need to be addedi.e. participants, physical evidence and process. 


\subsection{Components of Marketing Mix of Tourism}

Bennett \&Strydom (2001) have also confirmed the marketing mix as a combination of seven Ps in tourism marketing. These seven Ps encompass the factors responsible for the success or failure of products/services of tourism industry:

1. Products/service nature, quality/variety etc.

2. Placement that might involve the role of intermediaries or the reservation system,

3. Pricing involves the price of tourism product/service as compared to its quality,

4. Promotion involves the method of communicating about the tourism product/service to the tourists,

5. People are those employees who deliver the product/service to the customers (tourists) and some other customers who have an influence on these tourists,

6. Process means all the mechanisms through which the product/service is delivered to the tourists and

7. Physical evidence which means the environment in which the product/service is delivered to the tourists.

\subsection{Success Factors of Tourism Marketing Mix through the Lens of Sustainability}

As discussed in the section of sustainable cultural tourismthattheWorld Summit on Social Development (2005) has divided sustainability into three principal aims that add to the philosophy and social science of sustainable development. These aims or pillars of sustainable tourism development are i) Economic development; ii) Social development and iii) Environmental protection. For the attainment of these aims, UNEP and WTO (2005) have developed a 12 items agenda and have also suggested guidelines and policies to meet these aims. Since marketing is an important tool for economic development and sustainability, if used under the umbrella of these aims or agenda items and can positively help in promoting cultural tourism in Pakistan. The underlying section discusses the key success factors of marketing mix listed down after a detailed literature review in terms of sustainable tourism aims, that are not only the determinants of tourists satisfaction but also lead towards tourism sustainability. It seems important to mention here that, although these success factors of tourist satisfaction are grouped under specific and directly related sustainability aims, however, in the long run, these factors result in the overall tourism sustainability.

\subsubsection{Economic Viability}

The first milestone for achieving sustainability is to warrant the viability and competitiveness of tourism destinations and businesses (Dwyer \& Kim, 2003) to enable them to grow and bring long term benefits to the economy. The increase in competition has led modern businesses to focus more on different strategies that might lead to increase their competitive advantage over other companies (Lordache, Cebuc\&Panoiu, 2009). Therefore, designing proper marketing strategies for developing tourist sites is 
crucial for all the businesses and people involved in tourism (Aziri\&Nedelea, 2013). In this regard, generic strategies forwarded by Porter (1990)can play appositive role in destination competitiveness..Generic strategies are namely $i$-Cost leadership, iiDifferentiation and iii-Focus Strategy which can be used independently or in amalgam. Cost leadership strategy aims at competing by minimizing per unit cost of production in order to get a larger chunk of profit or to offer lower prices than competitors. Offering lower priced transportation, accommodation and other related products and services can lead to site competitiveness. However, it is substantial that low price strategy can be stimulated by bringing technological innovation in products and services also (Porter, 1990). For example modern transportation means are more comfortable as well as low on consumption of fuel (Peeters et al., 2006). On the other hand, differentiation strategy puts more emphasis on differentiation of product through quality, better services and unique features that competitors fail to provide(Porter, 1990). Uniqueness (Yunet al., 2008) maintenanceand conservation of archeological, historical and other cultural sites make them more attractive and differentiated from competitors (ICOMOS, 1998). Furthermore, norms, values(Budeanu et al., 2015) and tradition(Ortigueira\& Gomez-Selemeneva, 2011) of local culture as well as hospitality, knowledge(Kotler et al. 2008) and friendliness of local people(Neves, 2016) make the site more unique and differentiated (Aziri\&Nedelea, 2013;Suanmali ,2014).Still another modern and powerful stimulant of competitiveness is effective promotion of cultural sites and events (Ortigueira\& GomezSelemeneva, 2011) which can also be done through attractive brands, slogans and image building (Ritchie \& Ritchie, 1998; Carlsenet al., 2008; Al-Debi \& Mustafa, 2014). Marriot and Hilton are the best examples from hospitality industry that follow differentiation strategy. The role of above discussed generic strategies in achieving competitiveness is well explained by Evans, Campbell and Stonehouse (2003) who have described several ways of applications of generic strategies to travel and tourism industry as given in appendix-A. In a comparative analysis of hotels of Romania and US, Bordean, Borza\& Segura (2011) explored that the competitiveness of hotel industry of Romania is backed by a differentiation of having a great tourist accommodation capacity due to which most of the internationally known hotel chains have moved to Romania. Their findings showed that two of Porter's Generic Strategies i.e. low cost strategy and differentiation strategy were followed mostly by tourist friendly hotels of Romania whereas differentiation strategy was followed by hotels of America without due regard for lower cost. These findings demonstratethe importance of cost leadership and differentiation strategy for achieving competitive advantage in tourism industry.

\subsubsection{Employment Quality and Local Prosperity}

Local prosperity agenda aims at increasing the role of tourism in local development of the destination by creating more jobs, increasing per capita income and uplifting the economic status of local people through increased and locally retained expenditure by tourists (UNEP \& WTO, 2005). According to UNWTO (2014) tourism ensures not only income multiplier effect but also an employment multiplier effect on the economy. World 
Travel and Tourism Council (2018) also regardstourism a driver of job growth and economic prosperity that accounts for 1 in every 10 jobs globally and provides 1 in 5 of all new jobs produced in 2017.

However, to attain sustainability aim of UNEP and WTO (2005), it is not enough to opt only for the selling concept of marketing, but an integrated marketing program, as suggested by Kotler and Levy (1969), through improvements in product, communication, distribution and pricing should be incorporated. In case of tourism product, introducing economic, modern and innovative transportation means (Page, 1994, 1995; Peeters et al., 2006;Ortigueira\& Gomez-Selemeneva, 2011; Suanmali, 2014) and accommodation(Chung\&Petrick, 2012; Suanmali, 2014) should be ensured. It should also be ensured that tourists are provided with high quality products and other related facilities(Bagri \& Kala, 2015; Neves, 2016; Gargano\& Grasso, 2016).As people at the site are an important determinant of tourist satisfaction, Bramwellet al., 2000; Heath, 2002; Aziri and Nedelea, 2013; Budeanu et al., 2015; Potjanajaruwit, 2015 \& Heath, 2002) therefore, Bramwellet al. (2000) and Carlsen et al. (2008) advocate for heavy investment in the training and developmentofhuman resource (related directly and indirectly) as these are the key success factors of tourism growth. Moreover, Carlsenet al. (2008) further recommend proper training along with rewards to human resourcefor their development and tourism growth. therefore, special attention needs to be paid on training and development of the human resource,eitherrelated directly or indirectly and incentives in the form of rewards(Carlsenet al., 2008) should be ensured which helps in improving the number as well as quality of jobs (Goetsch\& Davis, 2014).

Kotler et al.(2008), Ortigueira\& Gomez-Selemeneva (2011), Aziri\&Nedelea, 2013;Suanmali (2014), Megatef (2015) andNeves (2016) suggest effective promotion as a determinant of tourism growth and therefore according toTkaczynski et al. (2009) that specific promotional strategies should be designed for different geological, cultural, economic segments of cultural tourism sites to maximize the role of tourism to the economic prosperity of the host destination. Pointed out by Fayeke and Crompton (1991), many destinations, despite their wide availability of attractions, fail to fulfill their tourism potentials because their promotion is not themed or targeted effectively. It seems evident from the above discussion that effective promotion of tourism sites, human resource development and tourism growth play an aligned role in stimulating local prosperity.

\subsubsection{Visitor Fulfillment}

The aim of visitor fulfillment has three main components i.e.

i) Safety of the tourists should be ensured; ii) The tourism service should increase their delight and satisfaction; and iii) Provision of tourism service must be without any discrimination of tourists.

Amir, Ismail and See (2015) and UNWTO (1996) regard safety and security as the basic determinant of tourism growth.Echtner and Ritchie (1991) also endorse the statement of UNWTO (1996) by arguing that creation and management of safe image of a destination is pre-requisite forits effective positioning and marketing strategy. Tourists being 
unfamiliar and temporary visitors to societies are unaware of the "safe" and "unsafe" regions or conducts. Therefore, they should be ensured about the safety and security of the site before their visit and also during visit to increase satisfaction.Morgan et al. (2002) also argue that having historical and cultural sites only is not enough to create an excellent experience for the tourists. Angeloni (2013) emphasizes that tourists are attracted by an overall affordable or easier destination and that is only possible by designing competitive strategies.

It is also interesting that although the success factors of tourism growth are related to sustainability in one or the other way but after all these factors as a whole lead to the satisfaction of tourists. A highly competitive tourism site with low prices(Cottrell et al., 2004), safety(Suanmali, 2014; Al-Debi \& Mustafa, 2014) and quality(Vanhove\& De Keyser, 1997; De Rojas \&Camarero, 2008; Carlsenet al., 2008; Ortigueira\& GomezSelemeneva, 2011; Bagri \& Kala, 2015\&Neves, 2016), ease of access (Suanmali, 2014) and comfortable infrastructure(Bramwell et al., 1996; Agarwalet al., 2010; Suanmali, 2014; Kirkpatrick, 2015) having a good image and branding(Ritchie \& Ritchie, 1998; Carlsenet al., 2008\& Al-Debi \& Mustafa, 2014); knowledgeable and friendly people (Bramwellet al., 2000; Heath, 2002; Aziri and Nedelea, 2013; Budeanu et al., 2015; Potjanajaruwit, 2015 \& Heath, 2002); beautiful landscape and environment (Ortigueira\& Gomez-Selemeneva, 2011); and easy process (Al-Debi \& Mustafa, 2014) ultimately gives a higher satisfaction to tourists. Although this satisfaction level and consumption patterns differ across tourists of different income, education, nationality, gender, age etc( Martins et al., 2012) however it is to remember, as added by UNEP and WTO (2005) and Hutchenson et al. (2009) that same service should be offered to all the tourists of any demographic attribute to maintain the equity.

\subsubsection{Community Wellbeing}

Community wellbeing is inherent to development of tourism. Most of the determinants of tourism success are directly or indirectly linked to the wellbeing of local community (Beeton, 2006). For example presence of main and minor roads (Pagem,1994 \& 1995) along with the availability of efficient transport(Carlsenet al., 2008); parking lots for vehicles, provision of information, signboards, accommodations (Bramwell et al.,1996) and all other infrastructure development(Cottrell et al., 2004 \&Kirkpatrick, 2015) positively add to the tourist satisfaction (McKercher, 1998;Buhalis, 2000;Prideaux, 2000 \&Sran, 2014). Availability of clean water, electricity, communication (Ortigueira\& Gomez-Selemeneva, 2011\&Suanmali, 2014)), proper sanitation facilities and safety are those success factors of tourism marketing which are the basic needs of a community.So, the development of tourism can be regarded as a driver of community wellbeing.

\subsubsection{Cultural Richness}

Different types of promotional strategies are used widely to enhance tourism. One of such strategies getting worldwide popularity is arranging local festivals. These may include cultural or religious festivals which in some cases are old and honored festivals presented in a new package while in other cases are newly introduced festivals with a basic aim of 
attracting new tourists to a region or destination. Arranging such festivals not only helps in increasing the demand for local tourism but also in creating a good image of the destination locally as well as internationally (Felsenstein\& Fleischer, 2003). That is why, nowadays culture has become an important tool for promoting a product especially tourism and is used as a differentiation element. Mega events, themes and other cultural activities are used to enhance the tourism promotion (Tresserras, 2004). Moreover, proper strategic planning of a festival may also increase the duration of a festival (Getz, 1997).Therefore, to attain the aim of cultural richness of sustainability, different culturally rich festivals and sites should be promoted(Ortigueira\& Gomez-Selemeneva, 2011) with sufficient interpretation (Carlsenet al., 2008) about the cultural site or festival. Moreover, special attention needs to be given for conservation of cultural sites(Alhemoud\& Armstrong, 1996) to increase the satisfaction of tourists.

\subsubsection{Physical Integrity}

Sustainable tourism also ensures uplifting the quality of urban as well as rural sites and does not harm the physical and visual degradation of the environment (UNEP \&WTO, 2005).Uplifting of tourist sites by quality and attractive presentation of cultural tourism destination through easy and attractive location, internal distribution, walkways, lightening, informative panels and contextualization are found as determinants of tourist satisfaction by De Rojas andCamarero (2008). It therefore, seems important that environmental purity and physical beauty of the site are basic aims of sustainable tourism development as well as tourist satisfaction.

\subsubsection{Environmental Purity and Biological Diversity}

Pollution free air, clean water and land with conservation of natural zones, environments and wildlife are the basic aims of sustainable tourism but are also important factors for tourist satisfaction. As evidenced by Cottrell et al.(2004) and Agarwalet al. (2010), clean and green environment are found as most important dimensions of tourist satisfaction and lead to sustainability as well.Similarly, Ortigueira and Gomez-Selemeneva (2011)also suggest protection of biodiversity, landscape, nature and climate as significant determinants of tourist satisfaction which at the same time are essential requirements of sustainability. 


\section{Conceptual Framework}

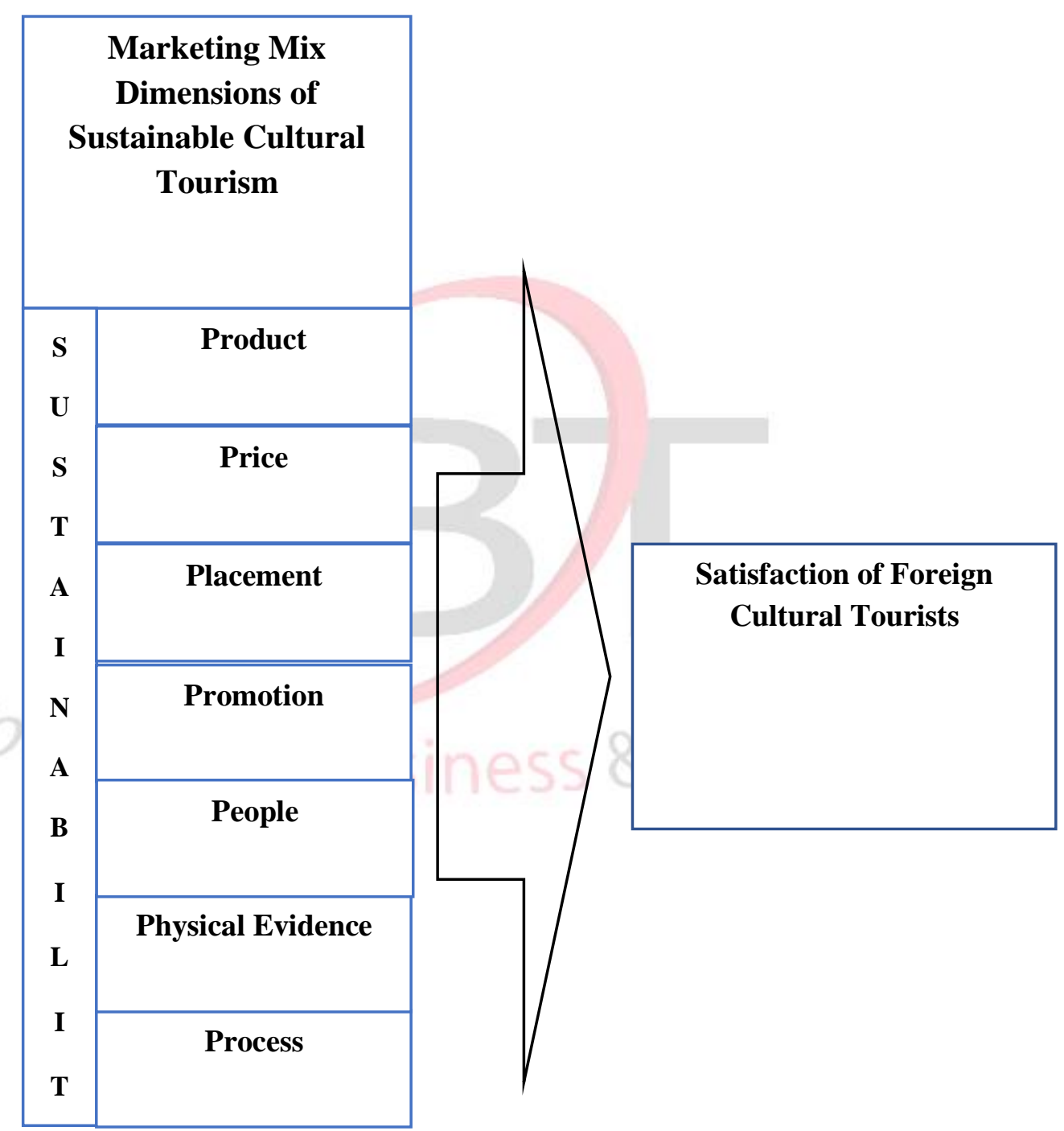

\subsection{Hypotheses}

H 1: Variable "Product" has a significant effect on satisfaction of tourists to cultural festivals, museums, and historical sites in Pakistan.

H2: Variable "Price" has a significant effect on satisfaction of tourists to cultural festivals, museums, and historical sites in Pakistan.

H3: Variable "Placing" has a significant effect on satisfaction of tourists to cultural festivals, museums, and historical sites in Pakistan. 
H4: Variable "Promotion" has a significant effect on satisfaction of tourists to cultural festivals, museums, and historical sites in Pakistan.

H5: Variable "People" has a significant effect on satisfaction of tourists to cultural festivals, museums, and historical sites in Pakistan.

H6: Variable "Physical Evidence" has a significant effect on satisfaction of tourists to cultural festivals, museums, and historical sites in Pakistan.

H7: Variable "Process" has a significant effect on satisfaction of tourists to cultural festivals, museums, and historical sites in Pakistan

\subsection{Methodology for the study}

The research philosophy of present study is based on positivism and its approach is descriptive and deductive.

\subsubsection{Population}

According to the World Economic Forum (2016) 965,498 foreign tourists visited Pakistan in the year 2016. No specific data was available as how many tourists visited each site. However, as Sikh pilgrims were restricted to their religious sites and their population known, therefore they were excluded from the whole population set of foreign tourists.Therefore, the rest of population served as the sample frame oftourists to cultural as well as other sites. Moreover, according to Khan (2017), no such distinction, on the basis of places visited by foreign tourists is made at the time of their entry to a province. Hence convenience sampling was done by contacting the available tourists at specific cultural site.

\subsubsection{Sample Size Determination}

By using Yamani (1967) formula, sample size was calculated at 95\% confidence level as 400.

\subsubsection{Discussion on Items}

Measurement of the marketing mix dimensions of sustainable tourism i.e. Product Price, Placement, Promotion, People, Physical Evidence and Process and tourist satisfactionwas done through a list of items found after a comprehensive literature review. All items except for demographic characteristics were measured on a five point Likert scale, that ranged from 1 = "Strongly disagree" to 5 = "Strongly agree".

\subsection{Analysis and Findings}

\subsubsection{Reliability of the study}

Cronbach's Alpha or Coefficient Alpha is a widely used consistency index which according to Gaur \& Gaur (2009) is the most reliable tool for measuring reliability of the scale. George and Malleery (2003); (Cooper, D. R., \& Schindler, P. 2003) and Hair et al. (2006) suggest the value of alpha greater than 0.60 as being acceptable.

The results of reliability test for the pilot-study of current research confirmed the consistency of items in the instrument (questionnaire). The reliability coefficient alpha values for all variables Product Price, Placement, Promotion, People, Physical Evidence and Process and Satisfactionwere higher than (0.6) level of acceptability. Hence, the results suggested that the questionnaire was a reliable instrument for measurement. 


\subsubsection{Exploratory and Confirmatory Factor Analysis: Assumptions Statistics}

Factor analysis that consists of exploratory and confirmatory analysis was conducted. Primarily the researcher used exploratory factor analysis by using Kaiser-Meyer-Olkin (KMO) and Bartlet test. Kaiser-Meyer-Olkin Test i.e.KMO is used to measure the appropriateness of data for Factor Analysis. It measures the adequacy of sample for each variable in the model and alsofor the complete model(Kaiser, 1974).

Table: 1. Assumptions Statistics for Factor Analysis

\begin{tabular}{lllll}
\hline Constructs & DCM & KMO & BTS & Sig \\
\hline Product & .007 & .758 & 1593.989 & $.000^{*}$ \\
Price & .006 & .865 & 1671.218 & $.000^{*}$ \\
Placement & .027 & .779 & 1168.606 & $.000^{*}$ \\
Promotion & .136 & .741 & 646.634 & $.000^{*}$ \\
People & .006 & .865 & 1671.218 & $.000^{*}$ \\
Physical Evidence & .006 & .893 & 1653.002 & $.000^{*}$ \\
& & & & \\
Process & .078 & .762 & 826.244 & $.000^{*}$ \\
Satisfaction & .005 & .758 & 1720.916 & $.000^{*}$ \\
\hline
\end{tabular}

From the above mentioned table it is evident that the values of $\mathrm{KMO}$ are above the threshold value of 0.60 (Kaiser, 1974)which indicate that there is no sample issue. The Pvalues in the above table are less than .05 which depict that the data set is accurate. After the conduction of exploratory factor analysis, following number of items was retained.

Table.2. Summary of Factor Analysis

\begin{tabular}{lllllll} 
Constructs & $\begin{array}{l}\text { Total No. } \\
\text { of Items }\end{array}$ & $\begin{array}{l}\text { No. } \\
\text { Items } \\
\text { removed }\end{array}$ & of & $\begin{array}{l}\text { Factor } \\
\text { Extracted }\end{array}$ & $\begin{array}{l}\text { Items } \\
\text { Retained }\end{array}$ & $\begin{array}{l}\text { Variance } \\
\text { Explained }\end{array}$ \\
\hline
\end{tabular}

\begin{tabular}{lclllll}
\hline 1. & Product & 12 & 2 & 1 & 10 & 72.908 \\
2. & Price & 6 & 2 & 1 & 4 & 69.742 \\
3. & Placement & 6 & 2 & 1 & 4 & 71.919 \\
4. & Promotion & 7 & 3 & 1 & 4 & 63.420 \\
5. & People & 7 & 3 & 1 & 4 & 69.742 \\
6. & Physical & 9 & 2 & 1 & 7 & 70.994 \\
& Evidence & & & & & \\
7. & Process & 9 & 2 & 1 & 7 & 71.342 \\
8. & Satisfaction & 7 & 3 & 1 & 4 & 54.759 \\
\hline
\end{tabular}

Method: Principle Component Analysis

\subsubsection{Confirmatory Factor Analysis and Structure Equation Modeling}


Confirmatory Factor Analysis (CFA) was carried out by using Structural Equation Model (SEM) to measure the construct validity and model fitness. A number of models are used in structural Equation Modeling (SEM) to show a relationship amongst observed variables in order to test a hypothesized theoretical model (Schumacker\& Lomax, 2010). In this study, SEM is used for confirming the theoretical model in which hypotheses are made that the observed variables explain the constructs and define relationship amongst these constructs. The assessment, generated by AMOS, is detailed below.Commonly fit indices include the Standardized Root-Mean-square-Residual (SRMR), the comparative fit indices (CFI), the Root-Mean-Square-Error-of-Approximation (RMSEA), Goodnessof-Fit-Index (GFI), Normed-Fit-Index (NFI) and Tucker-Lewis Index(TLI). Hancock \& Mueller (2010) suggested RMSEA, SRMR and at least one of CFI, TLI and NFI. They also recommended CFI, TLI, RMSEA, SRMR and Chi-square.

\subsubsection{Overall Factor Model for Tourists to Cultural Festivals, Museums and} Historical Sites

Following model exhibits the confirmatory factor analysis with fit indices of the overall factor model of Product, Price, Placement, Promotion, People, Physical Evidence, Process and Satisfaction. 


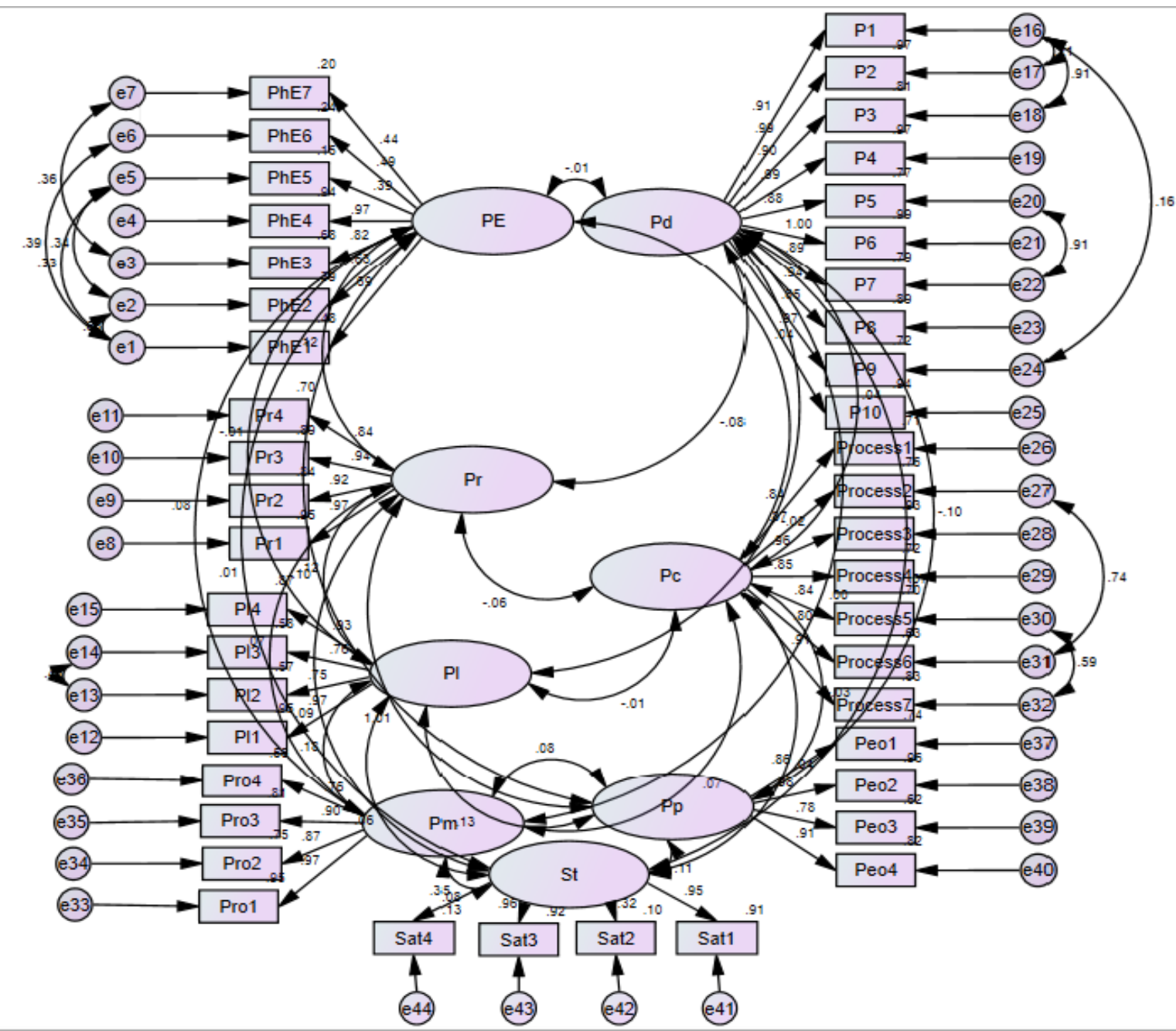

Figure: 4. Overall Factor Model for Product, Price, Placement, Promotion, People, Physical Evidence, Process and Satisfaction.

Table.3. Fit Indices for the Individual and Overall Factor Model for Tourists to Cultural Festivals, Museums and Historical Sites

\begin{tabular}{lllllcc}
\hline Variable & CMIN/DF & SRMR & GFI & CFI & TLI & RMSEA \\
\hline Product & 2.568 & .011 & .984 & .986 & .980 & .069 \\
Price & 2.946 & .008 & .996 & .997 & .932 & .077 \\
Placement & 3.081 & .058 & .976 & .921 & .910 & .058 \\
Promotion & 3.450 & .0058 & .996 & .997 & .982 & .103 \\
People & 2.315 & .0124 & .968 & .997 & .982 & .064 \\
Physical Evidence & 2.887 & .0293 & .978 & .985 & .976 & .076 \\
Process & 2.259 & .038 & .985 & .987 & .981 & .052 \\
\hline
\end{tabular}




\begin{tabular}{lclllll}
\hline Satisfaction & 2.416 & .027 & .901 & .899 & .868 & .066 \\
Overall Model & 1.544 & .0397 & .964 & .987 & .984 & .041 \\
\hline
\end{tabular}

Standardized Root-Mean-square-Residual=SRMR, Goodness-of-Fit-Index=GFI, Comparative Fit Indices=CFI, Root-Mean-Square-Error-of-Approximation=RMSEA, Normed-Fit-Index $=$ NFI and Tucker-Lewis Index $=$ TLI

The aforementioned Fit indices i.e. CMIN/d.f, SRMR, GFI, CFI, TLI andRMSEA were used for checking the goodness of fit for the factor model of Physical Evidence. The result of the factor modelsof individual variables i.e. Product, Price, Placement, Promotion, People, Physical Evidence, Process and Satisfaction depicted that the constructs have their own significant loadings and model is good fit according to the suggested value of Gaskin and $\operatorname{Lim}(2016)$, Hair et al.(2013) andHu and Bentler(1999).

\subsubsection{Multiple Regression Analysis of Tourists to Cultural Festivals, Museums and Historical Sites}

Following figure and table show the result of multiple regression analysis of independent variables i.e. product, price, place, promotion, people, physical evidence, process and dependent variable i.e. satisfaction.

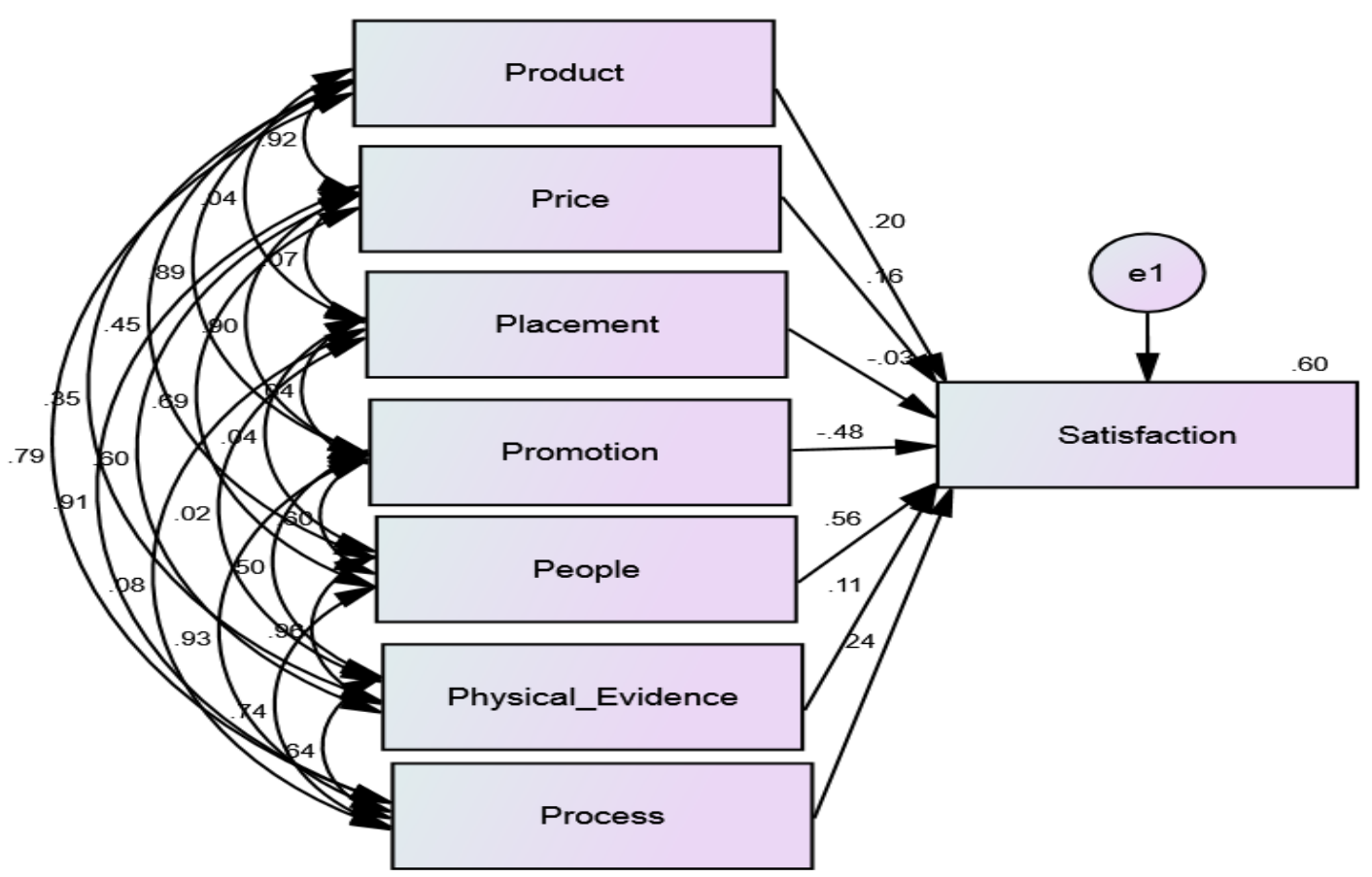

Figure:5. Multiple Regression Analysis of Tourists to Cultural Festivals, Museums and Historical Sites

Table.4. Regression Weights: Tourists to Cultural Festivals, Museums and Historical Sites 


\begin{tabular}{lllllll}
\hline & & & Estimate & S.E. & C.R. & P \\
\hline Satisfaction & $<---$ & Product & .202 & .213 & 1.393 & $* * *$ \\
Satisfaction & $<---$ & Price & .161 & .256 & .946 & $* * *$ \\
Satisfaction & $<---$ & Placement & -.027 & .064 & -.849 & .325 \\
Satisfaction & $<---$ & Promotion & -.480 & .237 & -3.595 & $* * *$ \\
Satisfaction & $<---$ & People & .558 & .143 & 4.259 & $* * *$ \\
Satisfaction & $<---$ & Physical Evidence & .114 & .215 & .971 & $* * *$ \\
Satisfaction & $<---$ & Process & .243 & .220 & 1.729 & .010 \\
\hline
\end{tabular}

$\mathrm{R}=0.771, \mathrm{R}^{2}=0.594, \mathrm{~F}=74.894, \mathrm{Sig}=0.000$

The regression coefficient $\mathrm{R}=0.771(77.1 \%)$ depicts that there is a relationship between dependent variable and independent variables. The coefficient of determination $\mathrm{R}^{2}=0.594(59.4 \%)$ depicts that $59.4 \%$ variation in tourist satisfaction(dependent variable) is explained by Product, Price, Placement, Promotion, People, Physical Evidence and Process (independent variables). The $\mathrm{F}=74.894$ and the significance value, Sig $=0.000$ shows that over all regression models is statistically significant, valid and fit. Based on statistical values "product" has a significant positive effect on tourist satisfaction $(\beta=0.202, p<.05)$, "price" has a significant positive effect on tourist satisfaction $(\beta=0.161, \quad p<.05)$, "placement"has an insignificant negative effect on satisfaction $(\beta=-0.027, p=0.325>.05)$, "promotion" has a significant negative effect on tourist satisfaction $(\beta=-0.480, p<.05)$, "people" has a significant positive effect on tourist satisfaction $(\beta=0.558, \quad p<.05)$, "physical evidence" has a significant positive effect on tourist satisfaction $(\beta=0.114, p<.05)$ and "process" has a significant positive effect on tourist satisfaction $(\beta=0.243, p=.01<.05)$ respectively.

\subsection{Discussion}

Results of Multiple regression revealed that product has a significant positive effect on tourist satisfaction. The result was consistent with the previous study of Agarwal, Choudhary\&Tripathi, (2010); Muala\&Qurneh (2012); Suanmali (2014); Kamau, Waweru, Lewa\&Misiko(2015) \&Magatef(2015). The beta coefficient for variable product is $\beta=0.202$ which means that one unit increase in productbrings 0.202 unit increase in tourist satisfaction.Foreign tourists showed keen interest in Pakistani culture and its diversity. It is evident from the fact that despite of having security fear and extremely rough roads to majority of these cultural sights, a large number of tourists still rush to these sights every year.

Cultural festivals of Pakistan studied in this research like Chilamjoshi festival, Shindur Festival and LokVirsaMela are highly enjoyed by foreign tourists. The unique cultural dance along with other rituals at Chilam Joshi Festival is of high attraction for tourists. Likewise, Shandur Festival with its amazing scenery and joyful celebrations is a major tourist attraction. However, the main weakness of these sites is their extremely difficult accessibility which nearly all of the tourists reported. LokVirsaMela, being conducted annually in the capital of Pakistan (Islamabad) has an ease of access through developed 
roads and is known for beautiful and unique cultural products made by craftsmen and women from all corners of Pakistan. Due to its comparatively secured status, nearly all the foreigners coming to Pakistan prefer to stay here. Therefore, a high majority of foreigners are found in this festival. The foreigners also show great love for the tasty and delicious food offered in Pakistani hotels, although the variety is limited in Chitral due to difficulty in transportation of necessity products ("Why Pakistan", 2017).

The museums of Pakistan contain the remains of early civilizations from thousands of years ago and are well maintained. However, the historical monuments, temples and monasteries are facing depletion and as reported by many tourists, there is no proper care and maintenance of these sites. Even then, foreigners show high interest in visiting these sites (Khaliq, 2011).

The price has a significant positive effect on tourist satisfaction. The result was consistent with the previous study of Muala\&Qurneh (2012); Suanmali, 2014; Potjanajaruwit, 2015; Kamau, Waweru, Lewa\&Misiko, 2015; Magatef, 2015). The variable price was found a significant positive predictor of tourist satisfaction with a $\beta$ coefficient value of 0.161 which means that for every 1 unit change in price there is a 0.161 unit increase in tourist satisfaction. The price for tourism product is divided into two main categories i.e. monetary and non-monetary prices. Monetary prices include the prices for entering into the destinations, prices of utility products etc. while nonmonetary prices include the costs other than money i.e. time taken to reach the destination and risk during the journey (Sran, 2014). The four questions retained in factor loading were;

Prices of food and services are reasonable.

Tour prices to Pakistan are suitable compared to neighboring countries.

I do not feel hesitation in visiting the cultural sites due to lack of security.

I am extremely worried that I could be a victim of terrorist attack.

Although price has theoretically a negative effect on demand and satisfaction, but in this study the nature of questions in variable price depict that a significant positive effect of price on satisfaction mean that tourists are satisfied with prices and security conditions in Pakistan. Moreover, it also demonstrates that tourists do not feel hesitation or fear in visiting different sites of Pakistan.

The placement has aninsignificant negative effect on tourist satisfactionwith a $\beta$ value of -0.025 . The result showed an inconsistency with the previous studies of (Muala\&Qurneh, 2012; Magatef, 2015 Raybould, 2009).

The promotion has a significant negative effect on tourist satisfaction. The result was consistent with the previous study of (Agarwal, Choudhary and Tripathi, 2010; Marcussen, 2011).Promotion was found a significant negative predictor of tourist satisfaction with $\beta$ coefficient value of -0.480 which means that a one unit increase in promotion brings 0.48 unit decrease in tourist satisfaction. Items retained in exploratory analysis of variable promotion were about provision of sufficient online 
information,enough advertisements in home country about cultural sites of Pakistan and sales promotion activities. Pakistan has always been promoted by international media as an unsafe destination for foreign tourists with no security of life. Therefore, foreigners hesitate to visit Pakistan ("Pakistan Ranked Fourth", 2017).

The variable people has a significant positive effect on tourist satisfaction. The result was consistent with the previous study of (Muala\&Qurneh, 2012; Chung\&Petrick, 2012; Aziri and Nedelea, 2013). The variable people showed a significant positive effect on tourist satisfaction. The beta coefficient value for people was $\beta=0.558$ which predicts that one unit increase in people brings 0.558 unit increase in tourist satisfaction. The positive and comparatively higher value of beta depicts that the variable people causes more satisfaction to tourists as compared to other variables. The people of Pakistan are very hospitable and have always shown warmth and love to foreigners who visit Pakistan. As evidenced by The British Backpacker Society (2018), the two backpackers of the British Backpacker Society, Samuel Joynson and Adam Sloper gave their feedback that the incredible hospitality of the local people and magnificent natural beauty of Pakistan have won their hearts. Accordingly, they travelled to 101 countries and found the hospitality of Pakistani people as outstandingly amazing. They shared their feelings in the following words;

"Pakistan is one of the friendliest countries on earth. So, prepare to be invited into people's homes, take more selfies than you can count, and have every preconception that you ever held about this area of the world changed forever" (Joynson\&Sloper, 2018).

Pakistani people are always ready to help and guide their local and especially foreign guests and would never let their guests get harmed in any way. They believe it to be their religious as well as social obligation to warmly welcome their guests with smile and in depth sincerity (Mander, 2016).

The physical evidence has a significant positive effect on tourist satisfaction. The result was consistent with the previous study of (Al-Debi and Mustafa, 2014; Iqbal, 2016) and the process has a significant positive effect on tourist satisfaction. The result was consistent with the previous study of (Muala\&Qurneh, 2012; Iqbal, 2016; Martin, 2015; Yang, 2010) respectively.Physical evidence was found a significant positive predictor of tourist satisfaction. The beta value for physical evidence was $\beta=0.114$ predicting a 0.114 unitincrease in satisfaction through one unit increase in physical evidence.

The significantly positive beta depicts that an increase in physical evidence causes an increase in tourist satisfaction. The scenic beauty and cultural richness of the sites is the main influence that tourists can't resist. However, the satisfaction of tourists can further be enhanced by proper arrangements for cleanliness of tourist sites.Most of the cultural tourist sites in Pakistan lack adequate sanitation facilities. Although the hotels at site are clean but these are not properly decorated for cultural festivals. The landscape of most of the sites is marvelous but still there are inadequate facilities of electricity and internet at hotels and motels. Some of the festivals like Lok-Virsa-Mela are conducted in a 
moderately hot weather in a dusty environment with no arrangements for shelter and improper sitting arrangements for tourists.

The variable process is a significant and positive predictor of tourist satisfaction with a beta coefficient value of $\beta=0.243$ depicting anincrease of 0.243 in tourist satisfaction with a unit increase in the variable process. The positive beta coefficient depicts that tourists are satisfied with the items of process.

\subsection{Recommendations and Conclusion}

1. Attraction of all the historical sights should be increased by augmenting through making accessibility easier especially to festivals sites in Chitral Valley like, Shandoor, Bamborit, Mastuj, Bruz, Rambur; Takht-Bhai and some areas of Swat Valley. Access to the historical site of Takht-Bhai should be made easy. All these efforts will make the tourism more sustainable and attractive.

2. The sustainability of tourism necessitates an immense need for paying special attention to the maintenance and presentation of historical sites as many of the temples, statues and monasteries are vanishing with seasonal variations (Taxila Regional Site Conservation for Global Heritage Fund, 2011 \&Ghani, 2017). Proper arrangement for lighting and cleanliness should be done.

3. It is highly recommended that the Government should construct and repair the roads towards all tourism sites on priority basis. According to "Flash back" (2012) construction of roads have always played the role of a double edged sword in socioeconomic changes of a place. However, it should also be ensured that the construction of roads and increase of transportation might not harm the natural resources like trees, atmosphere and beauty of the sites.

Pakistan Tourism Corporation should make use of the emerging trends in promotional activities around the globe. It should invest heavily in advertisements, showing a peaceful and loving nature of Pakistan and its people. A good relationship with previous tourists should be maintained through keeping contacts with them and greeting them on different occasions like birthdays, etc. Sufficient discounts should be offered on special occasions to Christians, Buddhists, Sikhs, Hindus and other communities. Moreover, internet blogs and social media should be used for enhancing a good publicity of different sites of Pakistan.

4. Although Pakistan's High Commission is doing efforts to promote its cultural tourism as on $70^{\text {th }}$ anniversary of Pakistan it has paid for London's double-decker buses to display different beautiful and representative pictures of Pakistan for four weeks to promote tourism (Tellis, 2017). The government of Pakistan should create an attractive and common slogan for Pakistan and should spread it across all forms of channels like other countries have created e.g. the country slogan of Malaysia is Truly Asia, Maldives' Sunny side of life, Thailand's Amazing Thailand etc. (Aiyer, n.d.)

5. Special trainings should be provided to the tour guides, waiters and managers at hotels and restaurants, salesmen and all the other staff that may come in contact to foreign tourists. According to Kotler, Bowen and Makens (2008) and Jeon and Choi 
(2012), satisfied employees lead to satisfied customers. It implies that in order to keep the tourists satisfied, all the related staff should be considered as an asset and must be provided with proper education and awareness programs.

6. The cultural sites should be decorated with cultural products and images demonstrating cultural richness. The cultural festivals should be arranged with maximum provision of facilities like clean environment, shelters (in case of rain and hot weather), proper lightning, shopping malls, five star hotels etc. However, policies should be made for environmental and cultural protection so that the rush of tourists might not harm the natural and cultural assets of the country. For beautification of historical sites, private local as well as foreign investors should be encouraged. Foreign tourists should be offered gifts of cultural products which will help in tangiblization of tourists' experience. It will also help in publicity of the destination and spreading a good word of mouth.

7. The process should be made easy to help tourists. Information about different cultural sites should be provided at different counter points like travel agencies, airports, and hotels. According to Kang et al. (2003), one of the largest market segment of tourism which is often overlooked is "visiting friends and relatives" (VFR) market. This segment has shown the highest profitability and highest expenditures per person on shopping. Therefore, in order to promote VFR, public and private tourism agencies should provide enough facilities at special events to the tourists. Pakistan Tourism Ministry should arrange conferences and seminars on the modern growth in the tourism business with execution of marketing P's practices. Conferences must involve the private and public segment agents, managers, tour operatives and give directives about how to improve Pakistan tourism sector.

8. Foreign and private investors should be encouraged for franchises and joint ventures in air services, hotels and theme parks. Investment in air services will make it easy to access the remote areas of Pakistan with more comfort whereas, investment in hotels and theme parks along cultural sites would increase the interest of tourists of every age in cultural sites. Moreover, foreign investors of different religions like Sikhism, Buddhism, Hinduism and Christians should be encouraged for maintenance of their religious cultural sites. It will help in the cultural richness of these sites.

9. Government authorities should ensure the education and awareness programs about tourism. The spread of its knowledge would surely upgrade the quality of human resourceincluding local residents, hotel staff, managers and other personnel. Tourism is major source of employment and its growth will directly increase the employment rate in the country resulting thus in local prosperity and economic viability.Ensuring training and development programs for local people will uplift the employment quality and local prosperity. Therefore, arrangement of such programs must be ensured.

10. Pakistan is among those nations of the world which have been experiencing deficiencies in its balance of payments for nearly the entire duration of its life. Advancement of tourism can enhance substantial growth in it and this is just possible from private sector's role in promoting tourism in Pakistan. Private sector should be 
encouraged and let introduce tourist friendly tourism services that may give comfort, convenience and luxury to all tourists (Aiyer, n.d.).

\subsection{Future Research Directions}

The present study was quantitative in nature. Qualitative study may also be conducted with the same objective. Studies should be conducted on determining the effect of other proposed variables of sustainable marketing on tourist satisfaction. The study was cross sectional in nature, longitudinal studies might also be conducted.

\subsection{Managerial Implications}

The study has provided a framework that might be of utmost significance for policy makers and project designers in uplifting the tourism of developing countries especially Pakistan to the level of sustainable tourism. The above discussed components of marketing mix of sustainable tourism provide clear guidelines for government and private organizations to plan for development projects that will boost tourism and sustainability side by side.

\section{References}

Amir, A. F., Ismail, M. N. I., \& See, T. P. (2015). Sustainable tourist environment: Perception of international women travelers on safety and security in Kuala Lumpur. Procedia-Social and Behavioral Sciences, 168, 123-133.

Blackwell, R. (2007). Motivations for Religious Tourism, Pilgrimage, Festivals and Events.In R. Raj \& N.D. Morpeth (Ed). Religious Tourism and Pilgrimage Festivals Management: An International Perspective (p. 37).United Kingdom: CAB International.

Boyd, S. (2002). Cultural and heritage tourism in Canada: Opportunities, principles and challenges. Tourism and Hospitality Research, 3(3), 211-233.

Echtner, C. M., \& Ritchie, J. B. (1991).The meaning and measurement of destination image. Journal of tourism studies, 2(2), 2-12.

Fuchs, G. \&Reichel, A. (2006).Correlates of destination risk perception and risk reduction strategies. Progress in Tourism Marketing, 161-170.

Hieu, V. M., \&Rašovská, I. (2017). Developing Cultural Tourism Upon Stakeholders' Perceptions Toward Sustainable Tourism Development in PhuQuoc Island, Vietnam. Research \& Science Today, 2(14).

Leslie, D \&Sigala, M(2005)Overview of Heritage and Cultural Tourism. International Cultural Tourism: Management, Implications and Cases. UK: Routledge

Magatef, S. G. (2015). The impact of tourism marketing mix elements on the satisfaction of inbound tourists to Jordan. International Journal of Business and Social Science, 6(7), 41-58. 
Oliver, R. L. (1980). A Cognitive Model of the Antecedents and Consequences of Satisfaction Decisions.Journal of Marketing Research, 17(4), USA: American Marketing Association. 460-469.

Petroman, I., Petroman, C., Marin, D., Ciolac, R., Vaduva, L. \&Pandur, I. (2013).Types of Cultural Tourism.Scientific Papers: Animal Science and Biotechnology. 46(1).385-388 Raj, R \&Morpeth, N.D (2007).Religious Tourism and Pilgrimage Festivals Management: An International Perspective. United Kingdom: CABI

RetrievedFrom:http://books.google.com.pk/books?id=vhnebGquwUIC\&dq=religious+to urism+definition\&source=gbs_navlinks_s

Shackley, M.(2003). Management Challenges for Religion-Based Attractions.In B. Garrod\& S. Wanhill (Eds).Managing Visitors Attractions: new directions (2 ${ }^{\text {nd }}$ ed.). U.K.: Routledge.

Sran, S.K. (2014).Role and Effectiveness of Marketing Services in Tourism. University of Euroregional Economy Poland. Retrieved on $10^{\text {th }}$ January, 2016 from: https://www.academia.edu/9492907/Tourism_Marketing_7_Ps

Tighe, A. J. (1991). Research on cultural tourism in the United States. In Tourism: building credibility for a credible industry. Proceedings of the Travel and Tourism United Nations Environment Program \& World Tourism Organization (2005a).Making tourism more sustainable: A guide for policymakers. Retrieved on $28^{\text {th }}$ Dec, 2016, from: http://www.unep.org/publications/search/pub_details_s.asp?ID-3566

United Nations Environment Program. (2005b). Marketing Sustainable Tourism Products.Nairobi, Kenya:United Nations Environment Programme and Regione Toscana United Nations World Tourism Organization. (2014).World Tourism Organization.

Retrieved from: http://torc.linkbc.ca/torc/downs1/WTOdefinitiontourism.pdf 